\title{
REFERENCES.
}

\author{
Albrecht and Ghon. Wiener klin. Woch., 1901, Bd. xiv. p. 984. \\ Bettencourt and Franca. Zeit. f. Hygiene, 1904, Bd. xlvi. p. 463. \\ Councilman, Mallory, and Wright. Epidemic Cerebrospinal Meningit/s, Boston, 1898. \\ Davis. Medical News, 1905, vol. 1xxxvi. p. 644 . \\ Fraenkel, C. Zeit. f. Hygiene, 1899, Bd. xxxi. p. 221. \\ Gwyn. Bulletin of the Johns Hopkins Hospital, 1899, vol. z. p. 112. \\ Haglund. Abstract Centralbl. f. Bakter. Referata, 1901, Bd. xxix. p. 268. \\ Leuhartz. Nothnagel's specielie Path. u. Ther., 1903, Bd. iii. Abt. 2, p. 310. \\ Lenhartz. Deatsches Archiv f. klin. Med., 1905, Bd. Ixxxiv. p. 81. \\ Lord. Centralbl. f. Bakter., Originale, 1903, Bd. xxxiv. p. 641. \\ Martini and Rohde. · Berliner klin. Woch., 1905, Bd. xlii. p. 997. \\ Möller. Mitteilungen a. d. Grenz. der Med. u. Chir., 1903, Bd. xii. p. 532. \\ Salomon. Berliner klin. Woch., 1902, Bd. xxxix. p. 1045. \\ von Lingelsheim. Deutsche med. Woch., 1905, Bd. xxx. p. 1017. \\ Warfield and Walker. Bulletin Ayer Clin. Lab., 1903, vol. i. p. 81. \\ Weichselbaum. Kolle and Wassermann's Handb. der path. Micro-organismen, Jena, 1903. \\ Weichselbaum and Ghon. Wiener klin. Woch., 1905, Bd. xviii. p. 625. \\ Weyl. Jahrbuch f. Kinderheilkunde, 1905, Bd. 1xi. p. 385. \\ White. Journal of Experimental Medicine, 1899, vol. iv. p. 425. \\ Winterstelner. Wiener blin. Woch., 1901, Bd. xiv. p. 996.
}

\section{A CASE OF PRIMARY THROMBOSIS OF THE LATERAL SINUS, RUNNING ITS COURSE WITH OPERATION, AND AT NO TIME HAVING ANY INVOLVEMENT OF THE MIDDLE EAR.}

\footnotetext{
By Frank M. Cunningham, M.D.,

LATE hOUSE SURGEON TO NEW YORK EYE AND EAR INFIRMARY; SURGEON TO EAR, NंOSE, AND THROAT DEPARTMENT, CITY HOSPITAL, MACON, GA.
}

Mr. H., aged twenty-eight years, occupation stable manager, single. Family history negative. Physical examination: heart negative; lungs, small area of flatness (almost dulness) at base of right; exaggerated tubular sound at left apex.

January $7 t h$. Patient complained of severe headache, pains in the back and legs, the pains in the legs being so severe that they were almost cramped, showing a decided spastic contraction. Temperature, $102^{\circ}$; pulse, 84 ; respiration, 16 to 18 .

Diagnosis. La grippe. Treatment: Mercurial purgation in the form of calomel $\frac{1}{4}$ grain every fifteen minutes until eight doses were taken. Half-ounce Epsom salts following morning; also a combination of quinine sulphate, phenacetin, and caffeine citrate.

Result. Temperature somewhat controlled and pains relieved. For three or four days patient felt much better, although there was some slight elevation of temperature during the afternoon or evening. 
January 12th. The temperature shows a decided tendency to remit. There was on this day a chilly sensation followed by a sharp, sudden rise of temperaturc. The chart shows fluctuation between $98^{\circ}$ and $104^{\circ}$. The headache, which had disappeared, now returned with increasing violence, being most severe over the frontal region. The lung condition was carefully watched and showed no change. Heart action good, the pulse rate never increasing in proportion to the rise in temperature. The respirations never were over 16 to 18 to the minute. The remissions of temperature were interpreted as strongly indicative of malarial infection. Repeated and persistent dosage with recognized remedies for this trouble failed to affect the condition, although the patient was thoroughly cinchonized. (It is proper to state, however, that examination of the blood failed to show the presence of the plasmodium of Laveran). The pain in the head, which had been most severe in the frontal area, became more diffused and involved the right parietal region, extending over the right side and affecting even the region of the occiput. These symptoms with such variations in temperature, the chilly sensations, and a dull, yellow apathetic appearance inspired a suspicion of the presence of a thrombus in one of the cerebral sinuses. A careful and thorough examination of the ear showed a positively normal condition of the middle-ear structures. The tympanic membrane had the usual dull, gray lustre of a normal drum, with the various anatomical outlines distinctly, accurately visible. Careful palpation over the mastoid area evinced no point of tenderness on pressure (antral or tip). There was no pain when pressure was made over the point of exit of the mastoid emissary vein. The symptoms continued for several days with varying degree of severity, apparently unaffected by the medication which had been ordered.

16th. The persistence of symptoms of fluctuation of temperature, with accompanying chilly sensations, induced the conviction that we were dealing with a process of septic nature. Repeated examinations of both ears showed no pathological condition. At no time during the course of the disease did the patient feel any pain, tenderness, or discomfort in the ear proper. At the examination on this day, however, on careful palpation of the mastoid area, a small spot of tenderness was located directly over the lowest part of the tip cell (the area of pain on pressure being limited to a spot about the size of a pea). The pain was not detected except on deep pressure, which indicated to us that the trouble was deep seated, and the pain was not felt on superficial pressure on account of a sclerosed cortex. A diagnosis of thrombosis of the lateral sinus was made and operative measures suggested for the relief of the condition. This advice was promptly refused. On account of the indefinite character of the symptoms and the difficulty of localizing these symptoms to the sinus as a definite focus of the infection, 
operation was not insisted upon at this time, though we felt that we had located the seat of trouble and accordingly were anxious to meet this most seriously urgent condition as early as possible.

20th. Symptoms unchanged. Pain area, although not changed in size, was becoming more acutely sensitive on pressure. Headache most severe, involving frontal, parietal, temporal, and base of occipital regions. Operation again advised and accepted. The patient was transferred to the hospital. The mastoid area was shaved and prepared in the usual manner. A bichloride compress (1:5000) was applied for three hours.

21st. Operation; gas and ether. A curved postauricular incision was made, beginning at a point directly over the centre and on a level with the lowest point of the mastoid tip, extending upward about one-half inch back of the pinna fold, to a point on the level with the upper attachment of the auricle. A straight posterior incision was made one inch long, and on a level with the external auditory meatus. The periosteum was retracted and the fibrinous attachments of the sternomastoid, trachelomastoid, and splenius capitis muscles severed from the mastoid tip with blunt curved scissors. A satisfactory exposure of the entire mastoid apophysis was thus assured. The usual steps of the classical mastoid operation were carried out. Beginning at a point directly behind the spine of Henle, in the suprameatal triangle, a section of bone was removed with a gauge. Care was taken to hug the linc of the posterior canal wall and only the superficial cortical structure was removed. The cortex was hardened and was healthy. The subcortical cells showed no evidence of the presence of any active inflammation. Here and there an area presented, filled with a material which resembled granulation tissue, yet it could not be said with any great degree of accuracy that it was pathological in nature. As a matter of fact, it gave the appearance rather of diploeic structure, somewhat reddened and congested. The mastoid antrum was opened and it, with the aditus ad antrum, carefully examined. There was no evidence of disease in either structure. There was, however, some softening in the tip cell, and this area was thoroughly curetted and cleaned. The lateral sinus was uncovered for a small area, but the exposure was not sufficient to allow a satisfactory examination. The shell-like bony covering forming the sigmoid groove in this area was then removed with curettes and forceps and the sinus uncovered from its knee through the descending portion, almost to its turn upward, where directly beneath the tympanum it joins the inferior petrosal to form the jugular bulb. The vessel was blackened and had every appearance of an acute, diseased condition throughout the exposed area. In removing the bony covering at the knee it was seen that the vein wall had undergone a softening, degenerative process. When an attempt was made to uncover the vessel in that area the tissues were easily torn, 
the tributary vessels with which this area is pregnant and abundant invariably tearing the friable wall, and some hemorrhage resulted. The flow, however, in our judgment, was not as free as it should have been. Accordingly, after cleansing the field of operation with alcohol (95 per cent.) and sterile water, a bistoury was plunged into the vein and the wall incised along its anterior surface throughout its descending portion. The flow from above was profuse, so the distal end was plugged with iodoform gauze. 'The upward flow was obstructed by what was evidently a parietal thrombus. A curette was introduced and the lumen of the vessel carefully searched. (This is a practice which I do not now advocate, and in the light of later knowledge is in my opinion to be condemned as a dangerous and unscientific surgical procedure. The fact that the clot formation was not broken up and particles of the infected matter dropped into the circulation of the internal jugular, with a consequent septic process in the lung, and the formation of metastatic abscesses in other parts of the body, was an act of chance; and I take no credit to myself for having subjected my patient to this most uncertain element, even though he did make a recovery.) The wound was packed with gauze, using separate packings for each area, after the method suggested by Dench, of New York. One packing, a small narrow strip, was put into the antrum, which has not been infected from start to finish of the casc; one strip into the area of the obliterated tip cell; and one, folded in the usual manner, into each of the sinus openings. 'The posterior incision was closed with sutures of silkworm gut. The original incision was not closed, the wound being left open to heal by granulation from the bottom. Recovery gradual, uneventful, and complete.

THE LYMPHATIO DRAINAGE OF THE PHARYNGEAL TONSIL. ${ }^{1}$

By George Bacon Wood, M.D., oF PHILA DELPHIA.

(From the Laboratory of the Wistar Institute of Anatorny.)

To understand the drainage of the lymph from the pharyngeal tonsil it is necessary to briefly recall the arrangement of the substernomastoid lymph glands and the retropharyngeal lymph glands. Theoretically and also practically the upper deep cervical lymph glands may be divided into two groups, the external or posterior group and the internal jugular group. Anatomically these two sets of glands can scarcely be separated, as they are closely related by position and are connected by numerous lymphatic anastomoses. The glands of the internal jugular group receive the efferent lymph vessels from the superficial glands of the anterior part of the head and 